\title{
Abstract
}

For researchers working within a critique of capitalism and its relation to knowledge production, it is problematic to use traditional research methodologies endemic to the very system being critiqued unless they are somehow altered. This article investigates the potential of schizoanalysis to provide conceptual tools for such an approach. Developed through the collaborative work of Deleuze and Guattari, schizoanalysis operates from the organic principle that knowledge is an indivisible part of the way we live in the world. However, schizoanalysis is not a research methodology; it inserts itself into research methodologies, warps them, and reproduces itself through them.

Key Words Deleuze \& Guattari, horizontalist methodologies, militant research, relationality, schizoanalysis

\section{SCHIZOANALYSIS AND COLLABORATIVE CRITICAL RESEARCH}

\section{ERIKA BIDDLE}

\section{Introduction}

According to sociologist Michel Maffesoli, "the attempt to organize our systems from one defined point is futile".[1] In the past two decades, in the health sciences and on other institutional fronts, new forms of community-based participatory research (CBPR) have emerged, calling for partnerships between community members and researchers to facilitate a more synergistic approach to projects involving human subjects, particularly those who are underserved. However well-intentioned these efforts may be, there is the spectre of capital at hand in these initiatives, which are often administered through organizations heavily funded by the state. From antecedent methodologies, they maintain the subject as the focus of study by an institutional researcher/ observer and involve the perpetuation of evidence-based practices that demand replicable results. This observer/ observed divide is inscribed with hierarchy and the understanding of knowledge as something static to be acquired and possessed.

This inheritance from traditional methodologies is fundamentally problematic for a horizontalist practice that emphasizes intra-subjective transformation (becoming-other) over relations between subjects. This paper investigates the potential of schizoanalysis to provide an alternative to traditional research methodologies. Schizoanalysis was developed through the collaborative work of French 'anti-psychiatrist' Félix Guattari and philosopher Gilles Deleuze. It has been used to effect change in education (from militant research to primary-school teaching and proliferate net-based learning environments); health care (radical nursing, e.g., revolts against "best evidence" practices); art (especially avant-garde and interventionist/tactical media practices); and grassroots activist organising. 
In contrast with traditional research methodologies, schizoanalysis is overtly 'political'. It is a critique of powerknowledge in the vein of Michel Foucault, who exposed the power dynamics that suffuse knowledge as systems of capitalist production. In this criticism, knowledge is lived rather than something to be possessed. As we are all participants in the production of a reality that is never static, but always becoming, with schizoanalysis the hierarchy of the observer/ observed is wiped out. Along with creating radical alternatives, schizoanalysis can be seen as a way of subverting or 'perverting' traditional methodologies for the purpose of critical engagement, rather than a methodology in itself.

\section{The emergence of schizoanalysis}

Schizoanalysis is a method that emerged out of the collaboration between Félix Guattari and Gilles Deleuze in AntiOedipus: Capitalism and Schizophrenia, Vol. 1. At the time, Deleuze was well known among the Parisian intelligentsia for his scholarly work on Kant, Spinoza and Nietzsche, and for his radicalization of film theory. Guattari was active in the psychoanalytic arena, with his practice falling left of the reigning heterodox Lacanian alternative to Freud. He was also well known among French radicals for his role in mobilizing the events of May 1968, when a campus insurrection at the University of Paris at Nanterre spread wildcat sympathy strikes throughout France that paralyzed the country, and for a brief moment seemed to herald a genuine social revolution. In the wake of the failed revolt there was a surge of theoretical writings from French authors inspired by the potential of the event; the body of texts they produced became referred to thereafter as 'la pensée soixante-huit' ['68 thought]. Deleuze and Guattari are two of the leading theorists of this group of writers, and their collective output has become the canon for much contemporary critical theory.

Deleuze and Guattari were interested in creating possibilities for radical individual autonomy in a repressive world. Situated in the political aftermath of May 1968, Anti-Oedipus draws upon Deleuze's commitment to an immanent ontology, the position of the social and political at the core of being, and the affirmation of difference over transcendental hierarchy, as well as Guattari's psychotherapeutic critique of the Freudian and Lacanian dependence on totalizing, referential myths (such as Oedipus, the great Other and the unconscious structured as language) for rearticulation and interpretation of all subjective histories via productive dissensus.

They are both theorists of difference; the kind of theory that is productive of change. Deleuze published Difference and Repetition in 1968 and his philosophical work on differ- ence is roughly contiguous with Jacques Derrida's work on différance as a critique of structuralist theories of language. Their ideas are also contemporaneous with Jean-François Lyotard's rejection of totalizing narratives through his work on postmodernism. Nevertheless, their work is distinctly not about language: it is about praxis. In Bruno Latour's We Have Never Been Modern, a central aspect of his thesis is the rejection of postmodernism as a version of linguistic constructionism, whereby either the discursive or material is privileged in the construction of knowledge.[2] Deleuze and Guattari's approach to knowledge, however, entails the intimate integration, interaction, intervention and subterfuge of the material and the discursive in every aspect of its constitution for the purpose of effecting change to the socius and not to reify representation.

Their works together were prepared as field guides, not polemics. Anti-Oedipus was their first collaborative effort to find a 'method' for provoking preexisting groups or arrangements to actively question their composition as such. This project continued in their follow-up volume, A Thousand Plateaus (1980) - where the critical activities grouped under the term "schizoanalysis" are given individual names, including: "rhizomatics", "nomadology", "deterritorialization", and "micropolitics" to highlight the various forms of intervention they make possible.

\section{Schizoanalysis as a research methodology?}

Schizoanaylsis encompasses an axis for "theory and action", with no fixed form or technique. But can schizoanalysis even be considered a research methodology, let alone a 'credible' one? Deleuze and Guattari would resist any declaration of credibility. Brian Massumi notes in his foreword to A Thousand Plateaus,[3] paraphrasing Deleuze, that "legitimate philosophy is the handiwork of 'bureaucrats' of pure reason who speak in 'the shadow of the despot' and are in historical complicity with the State". [ix] Any such charge of legitimacy in the domain of research methodologies - a regime of 'molar' truth - would draw the same criticism. Their 'methodology' is to reject the authority and tradition of method - "the received view of the world", the application of a finite and structured way of doing things, the logic of the assembly line applied to the production of human psycho-simulacra - and to accede to the infinitude of morphic desire, so that change and movement can occur.

There are no hierarchical dyads or reductionist comparisons in schizoanalysis, only differences produced by entities mutually embedded in a network. Each entity takes part in the enacting of mutable component entities, and is 'always 
becoming'. The possibility of change is always immanent, it is the positive force recognized as 'potential'. The prospect of cold, hard data collection and analysis from a detached entity is anathema to schizoanalysis as a lived methodology. "The multiple must be made".[4, p6]

The following is a sketch of what applied schizoanalysis could look like:

To begin, researchers are situated within the analytic body, and are neither central nor authoritative. The aim is to produce an 'interactive group dynamic'. [4] This undermines the traditional authoritarian/hierarchical relationship between analyst and analysand (or, the interviewer and interviewee). For schizoanalysis the process should be collective, and not governed by professionals and experts.

The mode of inquiry is playful, does not conform to logical reasoning, and promotes intellectual creativity. The researchers engage with the analytic bodies in everyday life through a process of connections and interactions. Ideas develop out of these very assemblages. Unlike more conventional research methods, schizoanalysis allows the inclusion of the researchers' voices; it is more interested in 'rendering visibility' than 'reproducing visibility'. It is about the production of possibilities (of social change), not mere expression. Expression, the collective operative goal of research methodologies, is the primary enemy as it poses a meaning outside of and detached from the process and hence blocks the process.

Schizoanalysis tends towards the experimental production of concepts, referred to by Deleuze and Guattari as 'lines of flight' (resistance). It is an experiential exercise in organization and self-direction of collective social arrangements involving intuitive, practical and reflective processes.

Applied to the almost-imperceptible matter of what makes us act, feel, and think, schizoanalysis as a research method is capable of producing warm bodies of data because it is not simply a reflective, theoretical exercise, but an experiment in organization and self-direction of collective social arrangements, producing new forms of self-organization, self-management, self-direction, etc. It endlessly generates possibilities rather than providing limits, constantly reorganizing these possibilities into new productive constellations, making delineation and distinction irrelevant. It works from the inside-out, rather than the outside-in - as even the most immersive ethnography does.

Schizoanalysis was conceived as an "open system"; there is no final word.[3] What schizoanalysis proposes is that desiring machines and their assemblages are NOT to be inter- preted; implausible readings may overlap, intersect, conflict, and are positively multiplicities. It was towards this end that Deleuze and Guattari developed (in A Thousand Plateaus) their theory of the rhizome. In botany, 'rhizome' describes a system of roots that expands horizontally and underground. It has become shorthand for radical democratization. In this instance, it is also a riff on Noam Chomsky's tree-based linguistic model for meaning-making. The six principles of the rhizome as listed by Deleuze and Guattari are: connection, heterogeneity, multiplicity, asignifying rupture, cartography, decalomania (the condition of infinite flexibility, adaptability and resistance to rigidity). When used as a research tool, the rhizome allows for multiple nonhierarchical interventions in data representation and interpretation wherein no one is the subject, everyone is a subjectivity.

\section{Schizoanalysis in action: Guattari's 'the patients' club' $^{\prime}$}

[T] he ministerial guardians having never given up on the idea of establishing certain norms for them [the patients] despite the fact that their true value consists in the inventiveness they show outside of the established frameworks. - Félix Guattari [5, p200]

What Deleuze and Guattari are attempting to provide with schizoanalysis is a strategy for mobilizing latent potentials of resistance within (and possibly beyond) existing institutions of social production, as they are located within capitalism, and other such hegemonic systems of organization. In Chaosophy, Guattari recounts an experience he had at Jean Oury's La Borde, a clinic devoted to studies in antipsychiatry and investigations into group therapy. La Borde was well known for its experimental approach to psychiatric care, including 'communalism'; at the time, this allowed for an unheard of degree of humanity for institutionalized patients. Guattari himself said he was shocked at the "familiar, friendly, human" [5, p188] aspect of the patients and the staff. Although Guattari does not provide a date for this experience, in his foreword to A Thousand Plateaus, Massumi places Guattari's early investigations into the "subject-group" as early as 1960.[3, p13; 6]

Oury invited Guattari to spearhead an experiment in developing an intrahospital committee - 'the Patients' Club' - a radical reorganization of the institution with the gradual goal of desegregating the doctor-patient relationship as much as that between medical staff and service personnel. This experiment was essentially schizoanalysis' first practice. Its goal being to mobilize the sick and the care personnel, it entailed "an internal mini-revolution". [5, p190] All service work was integrated with medical work - for example, the administra- 
tion of medications, patient assessments, and the cleaning of toilets - for a radically dehierarchizing reorganization of duties. According to Guattari's recount of the experiment, the doctors appreciated the enriched encounters and dialogue they had with the patients and although the service employees were initially reluctant to resume the additional responsibilities, Guattari writes, within a few months time, "the clinic's institutional landscape would change radically". [5, p190] The organization of the staff got more complex and 'rhizomatic' as tasks became more differentiated and activities within the institutional machine became more multiple. Although it may seem contra to schizoanalysis' ethos of 'no bosses, no masters', a group of supervisors was implemented to assess the dissonances and flows of the reorganization.

Guattari does not clarify the role of the directorial group, but instead he stresses that the experiment served to produce new subjectivities in each of the participants. He writes: "The supervisors created by the 'rotations', guided by the 'schedule', and actively participating in the 'information meetings', gradually became, with training, very different people from what they had been upon arrival at the clinic. Not only did they familiarize themselves with the world of madness... [and] not only did they learn new techniques, but their whole way of seeing and living was modified. More specifically, they shed that protective armor with which so many nurses, educators, and social workers guard themselves against an alterity that unsettles them... it was the same with the psychotic patients... they discovered a whole new relationship to the world". [5, p192] Guattari argues that intervention into the psyche of the psychotic, the doctor, and the service worker is one and the same not by way of some "projective equivalent" [5, p192] to the individual body or the individual self, but is pragmatically situated in collective daily life.

The experiment at La Borde, effectively an experiment in 'deterritorializing' the flows and patterns of daily life in the institution, redirected the dreary and empty repetition of medical roles into a productive, internal, communal re-creation of something virtually larger than the institution. Guattari writes, "It was not simply a matter of calling psychiatry into question, but also pedagogy.... As I see it, all social segments should undergo, step by step, a veritable molecular revolution, i.e., a permanent reinvention. In no way did I suggest extending the experiment of La Borde to the whole of society, no single model being materially transposable in this way. Yet it seemed to me that subjectivity, at any stage of the socius worth considering, did not occur by itself, but was produced by certain conditions, and that these conditions could be modified through procedures in a way that would channel it in a more creative direction". [5, p194] This experiment in the radical democratization of psychiatric care resulted in change within the wider social field. As Guattari concludes, by working day to day in this fashion with its community of doctors, service staff, and patients, La Borde found itself involved in wider global issues of "health, pedagogy, prison conditions, femininity, architecture, urbanism". [5, p195]

It is important to note, as Guattari mentioned above, that 'no single model of schizoanalysis is transposable'. Every experiment in schizoanalysis is a one-off with unduplicatable results. Each new configuration, situation, 'assemblage' is unique, and as such, each approach to it will be different. As a method, this allows for a great deal of flexibility and possibility, but not much in terms of direction or certainty of results. However, what this method does allow for is selfawareness of the ethics of positionality, reflexive criticism that provokes action, fluidity and experimentation, creative situation-based thinking and tangibly productive results.

\section{Schizoanalysis: becoming militant research, col- lective theorization}

We think of our practice as a double movement: to create ways of being militants that escape the political certainties established a priori and embrace politics as research (in this case it would be 'research militancy'), and at the same time, to invent forms of thinking and producing concepts that reject academic procedures, breaking away from the image of an object to be known and putting at the center subjective experience (in this case, it would be 'militant research').

- Colectivo Situaciones [7]

Methodology is traditionally a structured form of obtaining knowledge, based on the subject/object divide. Knowledge is something that is acquired, possessed; it is the property of the researcher or the institution. In other words, traditional methodologies reproduce the capitalist private property relationship in the epistemic sphere, thereby reifying knowledge. Schizoanalysis allows for the effective elimination of the subject/object divide inherent in other research methods as is appropriate in the epistemological overhaul of the scientific method brought about by quantum mechanics. There is no Archimedean point outside the system from which to observe it. The observer is within the system, and affects the observed by the questions the observer puts to it and is in turn affected by it. Observation is never neutral.

According to Deleuze and Guattari, we are all participants in the production of a reality that is never fixed, but always becoming. In outlining their work together, they describe their theories as a 'toolbox of concepts' and we "are all 
handymen: each with his little machines and each with his little toolbox".[8, p1] Schizoanalysis operates from the understanding that knowledge is not just something written on the page, stored in a hard drive, processed through a system, and given currency in an institution, but an indivisible part of the way we live in the world. Knowledge is being or becoming. Ludwig Wittgenstein said of language in his critique of the parallel reification of it performed by analytic philosophy, that it implies a 'whole form of life'. Knowledge too is part and parcel of a whole form of life, and forms of life are knowledge.

If the way we live is a form of knowing, then research into it must also be lived. This is the takeoff point for schizoanalysis. The de-reification of knowledge is itself political, but schizoanalysis takes things further by not simply accepting things as they are but seeking to be productive of change. It is a question of 'ethos': a researcher working within a critique of capitalism and its relation to knowledge production cannot use traditional research methodologies which are a part of the very system that is being critiqued unless they are somehow altered - like a recombinant virus - through schizoanalysis. Just like viruses are not living organisms in and of themselves, they need to insert themselves into living cells, schizoanalysis is not a research methodology in and of itself. It needs to insert itself into other research methodologies, warp them, and reproduce itself through them.

Should schizoanalysis be framed as a qualitative methodology or is it analogous to a methodology? It would seem that given Deleuze and Guattari's political commitments and view of knowledge/view of the world that 'methodology' is impossible. Their political-epistemic commitments are linked to other critical theorists of power-knowledge, and anti-capitalist, anti-authoritarian, anti-oppressive struggles, a sphere that rejects traditional ways of forming and understanding knowledge as infused with power politics and other forms of hierarchy. Writing from within that sphere, existing methodologies cannot simply be adopted, so schizoanalysis is part of the search for a radical alternative.

In the academic context, this search for a radical alternative has developed into an emergent field known as "militant research". [9] Militant research is indebted to Deleuze and Guattari's schizoanalytic practice of mapping transversal linkages between subjectivities, which stresses collective theorization and action as an alternative to the methods "at hand" in the Heideggerean sense. As such, militant research is not a specialized task, nor a process that only involves those who are traditionally thought of as researchers or academics. Militant research starts from the understandings, experiences, and relations generated through organizing, as both a method of political action and as a form of knowledge. It is a configuration of investigation and social research that expands possibilities for political action from the perspective of the theorist within and part of the multiple and overlapping cycles and circuits of struggle. Like schizoanalysis, militant research is deeply ethical (but not a meta-ethics). It involves making one's own rules and yet employs empathy towards reaching mutually shared goals. Militant research, with its close praxical relationship to schizoanalysis, holds potential for academics and researchers with ties to social movements, for engaged intellectual work, and especially for those trying to do radical work within institutional frameworks such as the university, the hospital, etc.

\section{References}

1. Maffesoli M. The Time of the Tribes: The Decline of Individualism in Mass Society. Sage: London; 1996.

2. Latour B. We Have Never Been Modern. Trans. Catherine Porter. Cambridge, MA: Harvard University Press; 1993.

3. Massumi B. Translator's Foreword: Pleasures of Philosophy. In: Gilles Deleuze and Félix Guattari. A Thousand Plateaus: Capitalism and Schizophrenia, Vol. 2. London: The Athlone Press; 1996; ix-xiv.

4. Deleuze G, Guattari F. A Thousand Plateaus: Capitalism and Schizophrenia, Vol. 2. Trans. Brian Massumi. London: The Athlone Press; 1996.

5. Guattari F. Chaosophy. Ed. Sylvère Lotringer. New York: Semiotext(e); 1995. p. 200.

6. Massumi, B. A User's Guide to Capitalism and Schizophrenia. Cambridge, MA and London, UK: The MIT Press; 1992.

7. Colectivo Situaciones. Something More on Research Militancy: Footnotes on Procedures and (In)Decisions. In: Constituent Imagination: Militant Investigations, Collective Theorization. Eds. Shukaitis, S., Graeber, D., with Biddle, E. Oakland, Edinburgh, West Virginia: AK Press; 2007.

8. Deleuze G, Guattari F. Anti-Oedipus: Capitalism and Schizophrenia, Vol. 1. Trans. Robert Hurley, Mark Seem and Helen R. Lane. Minneapolis: University of Minnesota Press; 1998

9. Holloway J. Change the World Without Taking Power: The Meaning of Revolution Today. London: Pluto Press; 2002. 
Contact Information for Author:

Erika Biddle

Doctoral candidate

York University

Communications and Culture

88 The Pond Road

Toronto ON M3J 1P3

Canada

Email: erika@autonomedia.org 